\title{
Water Challenges for Geologic Carbon Capture and Sequestration
}

\author{
Robin L. Newmark • Samuel J. Friedmann • \\ Susan A. Carroll
}

Received: 30 January 2009/Accepted: 8 January 2010/Published online: 3 February 2010

(C) The Author(s) 2010. This article is published with open access at Springerlink.com

\begin{abstract}
Carbon capture and sequestration (CCS) has been proposed as a means to dramatically reduce greenhouse gas emissions with the continued use of fossil fuels. For geologic sequestration, the carbon dioxide is captured from large point sources (e.g., power plants or other industrial sources), transported to the injection site and injected into deep geological formations for storage. This will produce new water challenges, such as the amount of water used in energy resource development and utilization and the "capture penalty" for water use. At depth, brine displacement within formations, storage reservoir pressure increases resulting from injection, and leakage are potential concerns. Potential impacts range from increasing water demand for capture to contamination of groundwater through leakage or brine displacement. Understanding these potential impacts and the conditions under which they arise informs the design and implementation of appropriate monitoring and controls, important both for assurance of environmental safety and for accounting purposes. Potential benefits also exist, such as co-production and treatment of water to both offset reservoir pressure increase and to provide local water for beneficial use.
\end{abstract}

Keywords Carbon capture and sequestration . Groundwater resources

R. L. Newmark ( $\square)$

National Renewable Energy Laboratory, MS 1713, 1617 Cole

Boulevard, Golden, CO 80401, USA

e-mail: robin.newmark@nrel.gov

S. J. Friedmann · S. A. Carroll

Lawrence Livermore National Laboratory, P.O. Box 808, 7000

East Avenue, Livermore, CA 94551, USA

\section{Introduction}

Despite concerns regarding the adverse impacts of continued use of fossil fuels, global reserves of the main fossil fuels, particularly coal, are large enough and cost low enough to ensure their continuing dominance of energy supply for the foreseeable future (World Energy Council 2004). The World Energy Council 2007 Survey of Energy Resources notes that some 850 billion tons of coal were reported as currently recoverable at end-2005, and over a trillion barrels of oil (World Energy Council 2007). Carbon capture and sequestration (CCS) has been proposed as a means to enable continued use of fossil fuels in a carbon emission-constrained world. The technology is conceptually simple; carbon dioxide is captured from sources such as electric power plants or other industrial sources, compressed, transported to the injection site and injected deep underground for storage. It is estimated that CCS could be used to achieve between 15 and $55 \%$ of the carbon emission reductions necessary to avoid dangerous levels of climate change (IPCC 2005a, b) and that achieving emission reduction goals will be less costly with CCS than without it (MIT 2007). Thus, CCS appears to be key bridging technology for transitioning to a carbon-constrained energy system.

Water is already an integral element of energy resource development and utilization. Substantial amounts of water are used in energy resource fuel extraction, processing, storage and transport. In 2000, thermoelectric power generation accounted for 39 percent of all freshwater withdrawals in the U.S., roughly equivalent to water withdrawals for irrigated agriculture (withdrawals are water diverted or withdrawn from a surface-water or groundwater source) (Hutson and others 2004; DOE 2007). CCS poses potential challenges to water resources. Carbon storage requires high purity carbon dioxide $\left(\mathrm{CO}_{2}\right)$ streams; there is a 
"capture penalty" of increased water use for currently available capture and compression operations (DOE-NETL 2007c). Injection of $\mathrm{CO}_{2}$ into subsurface formations displaces formation fluids; brine displacement and reservoir pressure increases are potential concerns (Nicot 2008; Zhou and others 2008). Leakage of $\mathrm{CO}_{2}$ or displacement of brines into fresh water formations are also to be avoided.

\section{Carbon Capture and Sequestration}

Carbon dioxide can be stored in multiple geologic targets. Saline formations have the largest capacity of over 2,200 Gt for N. America alone (DOE-NETL 2008). Depleted oil and gas fields have the additional potential for $\mathrm{CO}_{2^{-}}$ enhanced oil and natural gas recovery. There is also potential to enhance gas recovery in conjunction with storage in unmineable coal seams. Injection as supercritical $\mathrm{CO}_{2}$ translates to storage depths generally in excess of $1000 \mathrm{~m}$, commonly between 1000 and $5000 \mathrm{~m}$. Enhanced oil recovery using available $\mathrm{CO}_{2}$ could dramatically increase U.S. oil production before going into permanent "storage". Based on studies of EOR applied to the six major producing U.S. basins, about 43 billion barrels of U.S. oil is accessible using current EOR processes; an additional 41 billion barrels is technically recoverable using more advanced, "next generation" $\mathrm{CO}_{2}$-EOR methods (e.g., Ferguson and others 2008; Kuuskraa and Koperna 2006) (Fig. 1). These figures compare favorably with the 186 billion barrel cumulative production to date.

The Earth's crust is configured to trap large volumes of $\mathrm{CO}_{2}$ indefinitely. Multiple mechanisms work at different time and length scales, described in detail by others (e.g., Johnson and others 2004, Johnson and others 2005) (Fig. 2). A combination of physical and chemical processes serve to trap the $\mathrm{CO}_{2}$; over time, risk of unintended $\mathrm{CO}_{2}$ migration

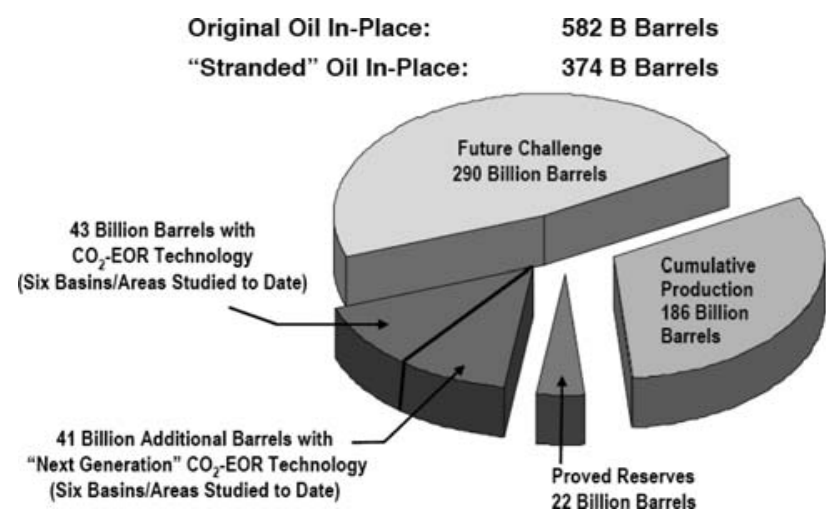

Fig. 1 Oil reserves estimated for six U.S. basins: potential exists for dramatic increases in production with $\mathrm{CO}_{2}$ EOR before going into permanent $\mathrm{CO}_{2}$ storage (after Kuuskraa and Koperna 2006) decreases and permanence increases. Initially, injected $\mathrm{CO}_{2}$ forms a plume that ascends towards the sealing unit (caprock) based on the density contrast between the $\mathrm{CO}_{2}$ and formation waters. Plume migration is constrained by the permeability structure of the storage formation by physical (structural and stratigraphic) trapping, in much the same manner that oil or gas are found in structural traps. The $\mathrm{CO}_{2}$ displaces formation fluids in the pore spaces, and some of the $\mathrm{CO}_{2}$ becomes bound by capillary forces; this is residual phase trapping. As the immiscible plume equilibrates with the formation waters, intra-plume aqueous $\mathrm{CO}_{2}$ concentrations increase to their solubility limit, while $\mathrm{pH}$ decreases; this is solubility trapping and represents the critical forerunner of the mineral-trapping mechanisms. Over the longest timeframe, $\mathrm{CO}_{2}$ precipitates as carbonate minerals; Johnson and others (2005) have described four distinct precipitation mechanisms that may occur in either formation or cap rock. Interestingly, their results indicate that mineral precipitation in cap rock may serve to decrease both porosity and permeability, thereby significantly improving cap rock integrity and improves hydrodynamic containment of immiscible and solubility-trapped $\mathrm{CO}_{2}$.

The U.S. is well endowed with sequestration resources (Fig. 3). A wide range of oil and natural gas fields and coal beds exist where $\mathrm{CO}_{2}$-enhanced product recovery is potentially possible through EOR or enhanced coal bed methane (IPCC 2005a, b). Saline formations are present in most regions. Many such resources are located near major $\mathrm{CO}_{2}$ sources. Current efforts at both the state and federal level are refining estimates of sequestration resources (e.g., DOE-NETL 2008; CEC 2007). Ideally, sequestration would be located close to $\mathrm{CO}_{2}$ sources, thus minimizing the transportation costs; there are numerous opportunities for sequestration either co-located or nearby many of the primary $\mathrm{CO}_{2}$ sources (i.e., coal-fired power plants).

Water Use in Energy Production; What are the Penalties for Carbon Capture and Sequestration?

As described in the DOE Report to Congress on the interdependency of water and energy (DOE 2007), water is an integral element of energy resource development and utilization, and therefore important to CCS. The water intensities for fuel extraction and processing range from several to tens of gallons/MMBTU for conventional fuels such as coal, oil or even nuclear fuels to in the hundreds to thousands for more advanced processes such as enhanced oil recovery (using steam), hydrogen or biodiesel production (including irrigation). While water withdrawals for power generation can range widely depending on the technology (e.g., from tens to 10,000 s of gal/MWhe), actual consumption is generally in the tens to hundreds of gal/MWhe range. New cooling technologies (such as dry 
Fig. 2 U.S. sequestration resources (lower 48 states) (from MIT 2007)

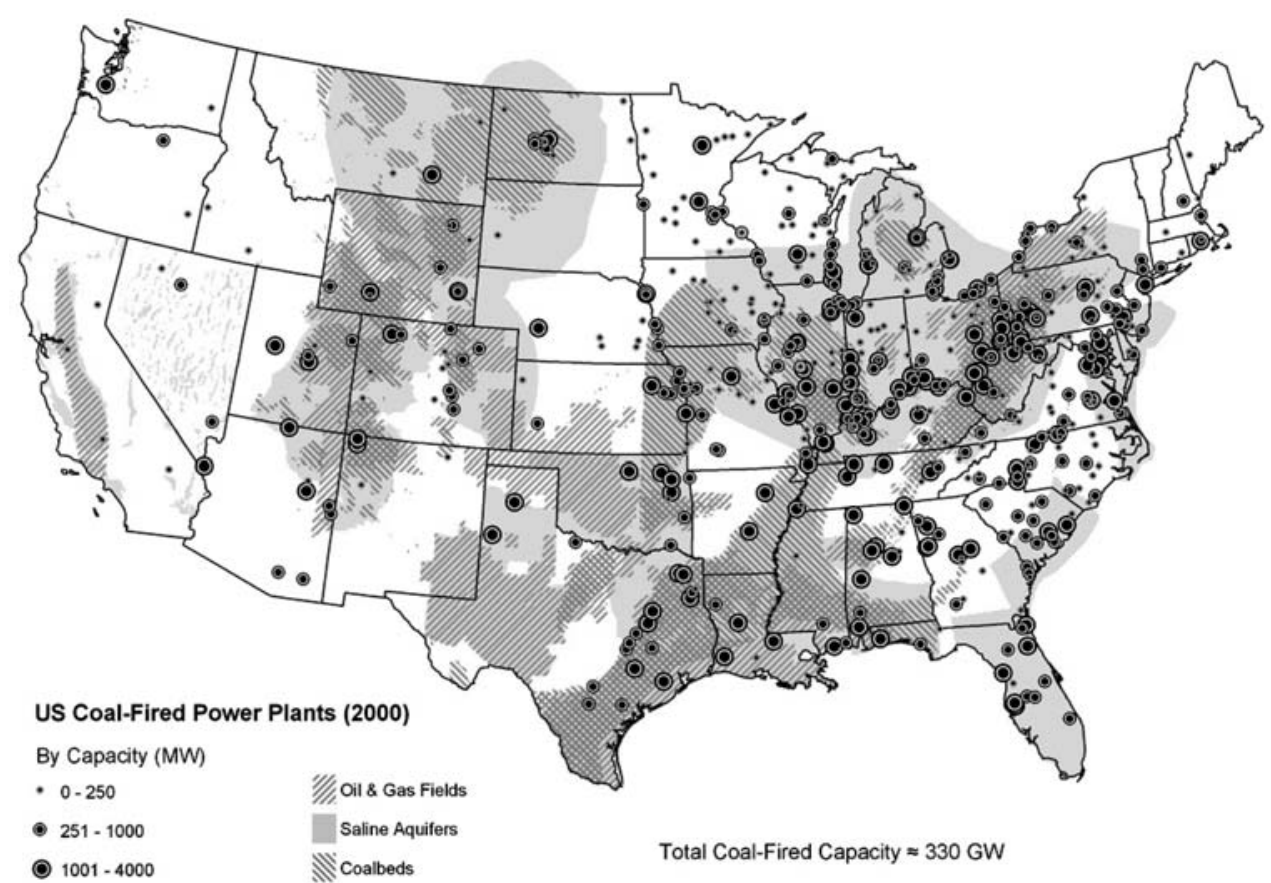

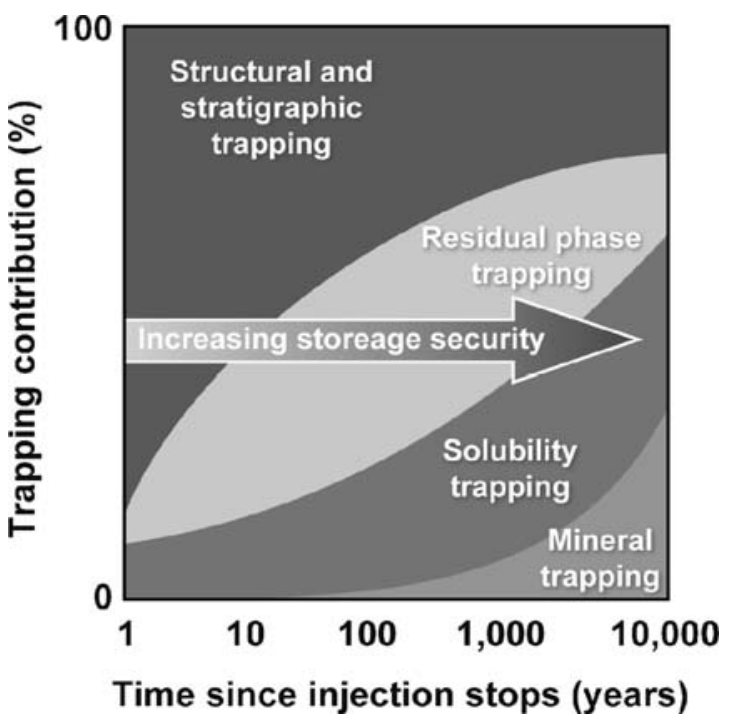

Fig. 3 Sequestration trapping mechanisms and storage security over time (after IPCC 2005a)

cooling) can reduce overall water usage (EPRI 2004). However, some of the highest water consumption rates (near or over $1000 \mathrm{gal} / \mathrm{MWhe}$ ) are associated with new technologies such as solar power using cooling towers and geothermal (DOE 2007). Projected energy demands and water constraints suggest that constraints will grow for energy development and power plant siting. These demands are complex, as different energy conversion processes have different water quality requirements.

Water is used directly for hydroelectric generation and is used extensively for cooling and emissions scrubbing in thermoelectric generation. In a recent study, cooling tower uses accounted for $80-99 \%$ of the raw water usage for various fossil plants (DOE-NETL 2007a). Other uses included slurry, quench, ash handling, humidifier, condenser and flue gas desulfurization (Fig. 4).

Carbon storage requires high purity $\mathrm{CO}_{2}$ streams and there are multiple pathways to capture and separate large volumes of $\mathrm{CO}_{2}$ : post-combustion capture, pre-combustion separation and oxyfiring. These capture processes require additional water for chemical and physical processes. They also require auxiliary power, also termed "parasitic " load, which lowers the net exported power. Alternatively, to keep the same power output requires additional use of coal and water.

The water issues are different for each capture process. Post-combustion capture separates $\mathrm{CO}_{2}$ from nitrogen using chemical sorbents such as amines. This process is generally the least costly of the currently-available commercial processes, but it is generally the most waterintensive. The additional water required for solvent-based carbon capture technologies is largely due to the additional cooling water requirements (DOE-NETL 2007c). In precombustion separation, the fuel (coal, pet-coke or biomass) is first gasified, creating syngas. Using a water-shift reaction, the syngas can be chemically shifted; the resulting hydrogen and $\mathrm{CO}_{2}$ can be separated using physical sorbents (e.g., the Selexol process). The additional water used for this capture technology is due to the increased cooling load required to further cool the syngas before entering the Selexol process and steam for the water gas shift reactor (DOE-NETL 2007c). The U.S. DOE recently conducted 
Fig. 4 Comparison of raw water usage for various fossil plants (from DOE-NETL represent different gasifiers, with different water requirements. NGCC represents natural gas combined cycle, PC Sub and PC Super represent pulverized coal, subcritical and supercritical configurations, respectively 2007a). E-Gas, Shell and GE

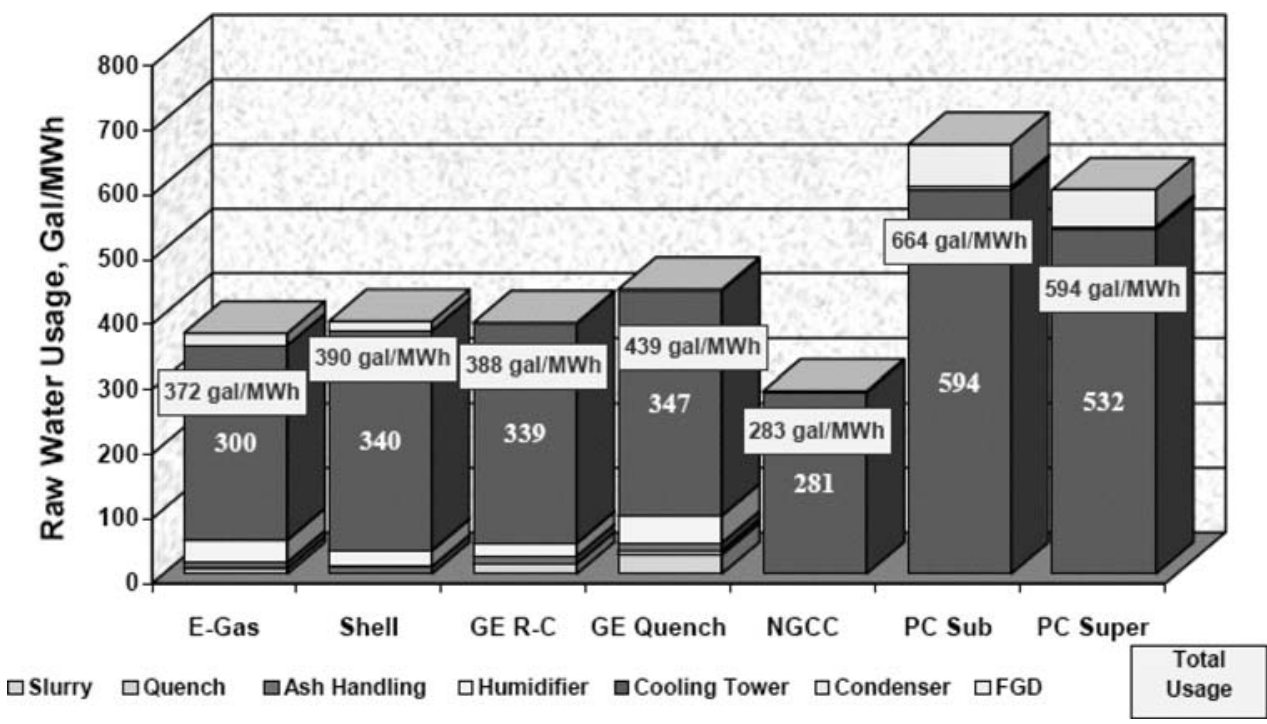

Fig. 5 Water demand and usage for various fossil power plants (from DOE-NETL 2007b). GE, CoP (E-gas) and Shell represent different IGCC plants utilizing different gasifiers. Other annotations as in Fig. 4

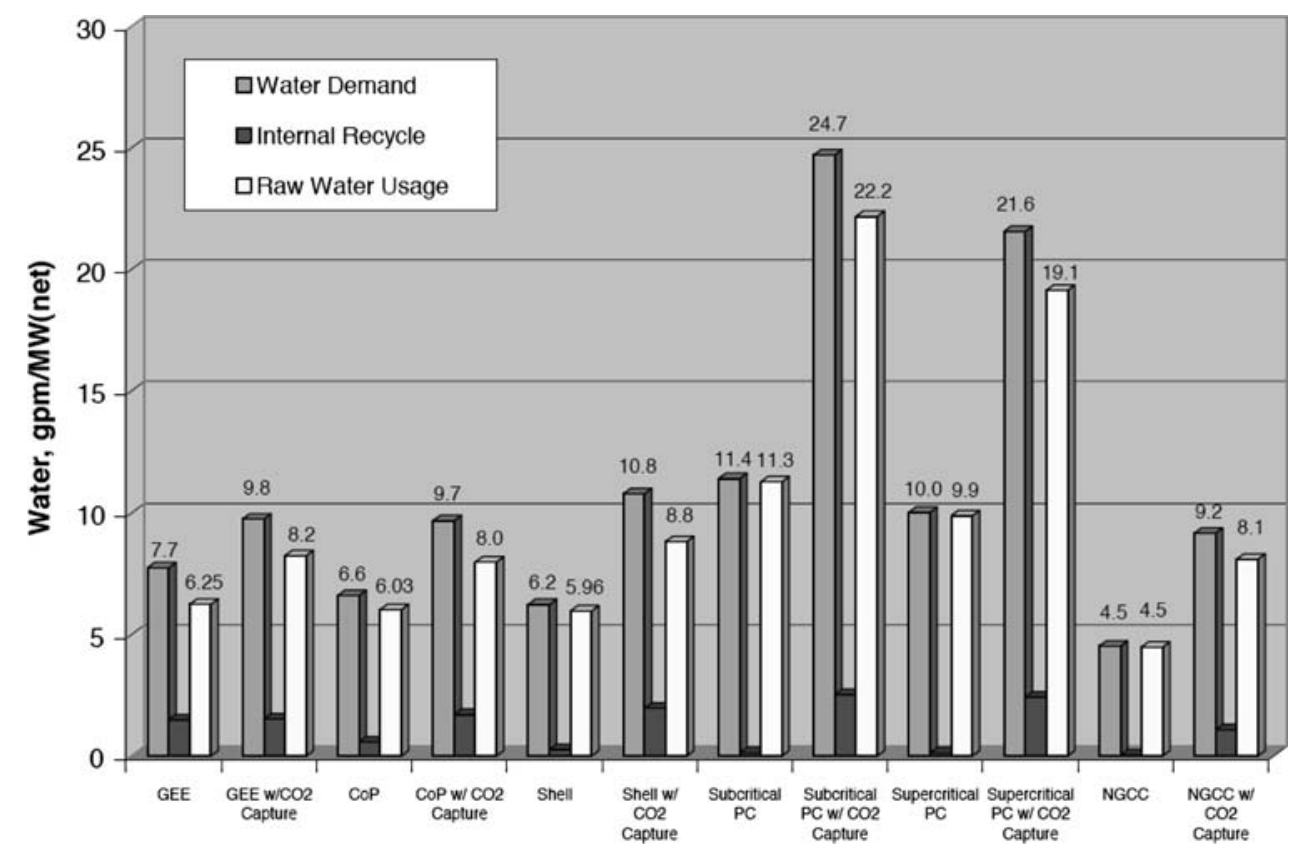

studies of the relative water usage for a nominal $90 \%$ carbon capture rate for various fossil fuel plants, including pulverized coal using amine capture, integrated gasification combined cycle (IGCC) plants with Selexol (physical sorbent) capture, and natural gas combined cycle (NGCC) with amine capture (DOE-NETL 2007b, c) (Fig. 5). Cooling continued to be the primary water use, ranging from 71-99\%. Among the key findings regarding the "capture penalty" for water use was the following:

$\mathrm{CO} 2$ capture increases the average raw water usage for all three technologies evaluated, but the increase is lowest for the IGCC cases. The average normalized raw water usage for the three IGCC cases increases by about 37 percent due primarily to the need for additional water in the syngas to accomplish the water gas shift reaction and the increased auxiliary load. With the addition of $\mathrm{CO} 2$ capture, $\mathrm{PC}$ normalized raw water usage increases by 95 percent and NGCC by 81 percent. The large cooling water demand of the Econamine process drives this substantial increase for PC and NGCC. (DOE-NETL 2007b)

In another study, the U.S. DOE compared the relative water requirements for new pulverized coal and IGCC plants with and without carbon capture (DOE-NETL 2007c) using the cost and performance impacts associated with CCS technologies on coal-based power plants (DOENETL 2007b) (Fig. 6). Water usage increased by about $100 \%$ for the pulverized coal plants, by about $30 \%$ for the 
Fig. 6 Relative water usage for new pulverized coal (PC) and integrated gasification combined cycle (IGCC) plants (after DOE-NETL 2007a). Note the IGCC data are averages of three different gasification technologies
Relative Water Usage for New PC and IGCC Plants

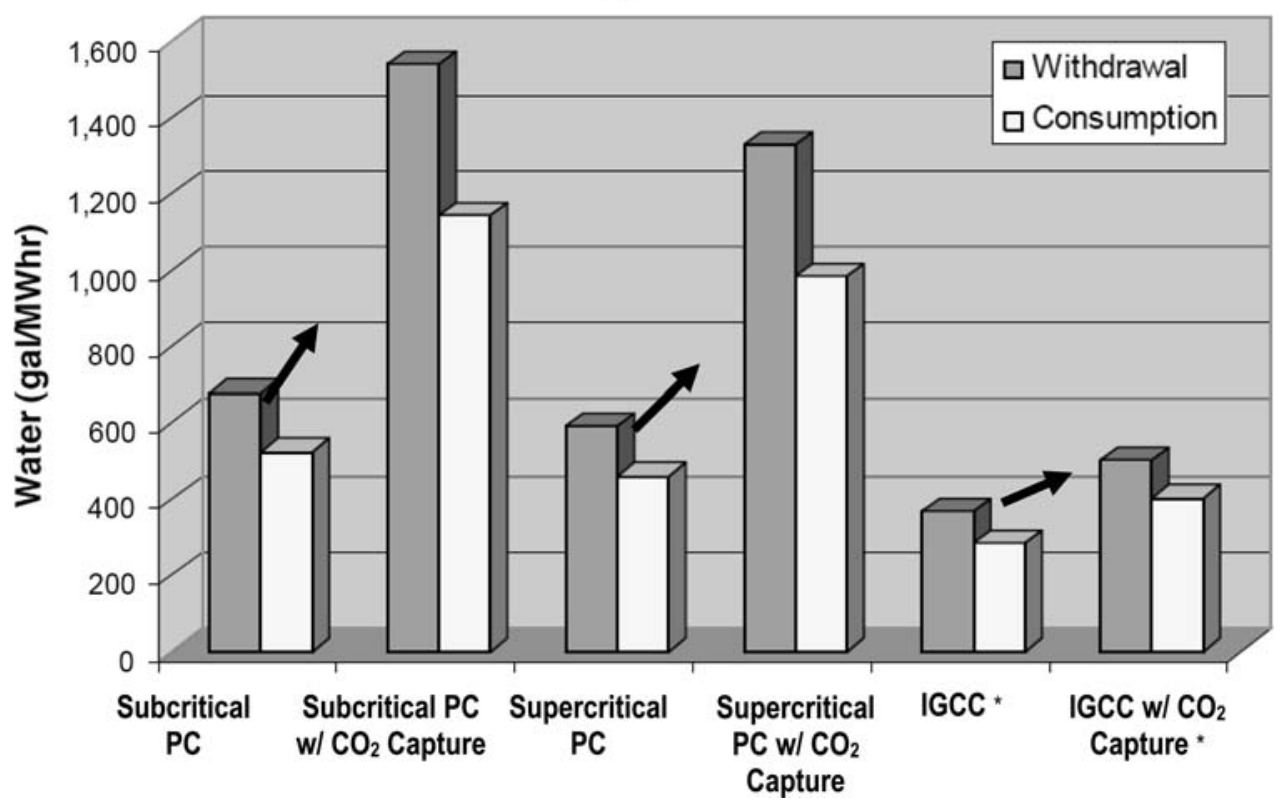

average of the three gasification technologies detailed in the report.

In oxyfiring, oxygen is separated from air and combusted with the fuel; the product is $\mathrm{CO}_{2}$ and steam, which can be readily be removed by compression. The primary water usage occurs in the air separation and flue gas condensation, compression and purification plants; the makeup water requirements will be similar to those listed by the DOE report for the IGCC and NGCC plants (Minish Shaw, Kevin Fogash, personal communications, 2008). There is no "capture penalty" for oxyfiring, as $\mathrm{CO}_{2}$ capture is more directly integrated into the process.

\section{Subsurface Behavior}

As $\mathrm{CO}_{2}$ is injected into a formation, it displaces formation fluids wherever a pressure gradient develops in response to injection (e.g., Johnson and others 2005). Less dense than the formation fluids, the immiscible $\mathrm{CO}_{2}$ 's rise towards the caprock will be governed by several constraints. The density contrast between $\mathrm{CO}_{2}$ and formation waters and the absolute formation permeability will determine the injection overpressure required to achieve a given influx rate, which eventually translates to a corresponding pressure anomaly along the caprock interface. A second pair of constraints include the saturation-dependent relative permeability of the formation to immiscible $\mathrm{CO}_{2}$ and the pressure-dependent volumetric expansion of this phase during ascent, effectively controls dynamic plume configuration. Various groups have modeled different aspects of plume behavior, from the more physical plume dynamics (e.g., Kumar and others 2007) to the reactive transport and trapping evolution (e.g., Johnson and others 2004) and interactions with the cap rock (e.g., Johnson and others 2005). While it is expected that the regulatory framework will restrict CCS to injection of high purity streams (e.g., EPA 2008c), efforts to explore the geochemical interactions of the $\mathrm{CO}_{2}$ on brine and formation minerals (e.g., Crandell and others 2008) provide insight into the potential impacts of less pure steams.

Recent studies have focused on large-scale changes in the storage formation and neighboring units due to $\mathrm{CO}_{2}$ injection (e.g., Zhou and others 2008; Nicot 2008). These two studies contrast very different approaches. Zhou and others consider injection of dense $\mathrm{CO}_{2}$ into layered sandstone/shale sequences, and perform sensitivity studies on the permeability of the seals. They assess the time and spatial evolution of pressure and brine displacement from injection into a single well. By contrast, Nicot explored the conditions under which shallow groundwater would be impacted by up-dip displacement of brines, modeling an injection of water instead of $\mathrm{CO}_{2}$. Both considered laterally unbounded storage formations. Despite the differences in approach, the two studies reach similar conclusions regarding the hydrodynamic response. As injection progresses, pressure increases within the injection formation over a relatively large region. The pressure pulse travels much faster than the mass of the $\mathrm{CO}_{2}$ plume, which has the potential to displace reservoir fluids swiftly, far from the $\mathrm{CO}_{2}$ plume itself. Outside the injection zone, the pressure increases are low. Pressure perturbations may reach shallow aquifers, causing fluid displacement. Lateral brine flow velocities induced by $\mathrm{CO}_{2}$ injection are relatively small. Vertical velocity of brine displacement through sealing units is negligibly small except where localized high-permeability flow paths occur. 
A number of techniques exist today to monitor and verify $\mathrm{CO}_{2}$ plumes. They include geophysical methods such as seismic and electrical imaging methods that detect changes due to the contrast between the $\mathrm{CO}_{2}$ and the formation matrix and fluids, sensors that measure pressure, temperature and $\mathrm{pH}$ changes indicative of the plume, surface measurements such as soil gas, LIDAR, hyperspectral, surface tiltmeters, direct sampling of fluids and gases, the use of natural and introduced tracers, and instruments to measure stress/strain changes. An excellent review of monitoring methods can be found in the recent California Energy Commission staff report (CEC 2007). The arsenal of techniques applicable for detecting the migration of displaced formation fluids into other fluid-bearing units is much smaller, because the contrasts between the displaced fluids and those they are interacting with is much smaller.

\section{Groundwater Concerns}

\section{Leakage}

A hazard risk framework is being developed to address the hazards resulting from sequestration. The hazards must be identified, their risks quantified, and their operational implications clarified (e.g., Wilson and others, 2007 Friedmann 2007). While the range of recognized hazards includes atmospheric releases, groundwater degradation and crustal deformation, here we focus on those hazards that affect groundwater. Groundwater hazards stem from different leakage scenarios; well leakage, fault leakage or cap rock leakage (Fig. 7). While all pose potential risks, site characterization and proper system design and operation should prevent leakage from the latter two. Wells represent the main hazard to geologic sequestration site integrity (MIT 2007), as these are places where the physical and chemical trapping mechanisms are disrupted. There is a good understanding of well failure modes due to

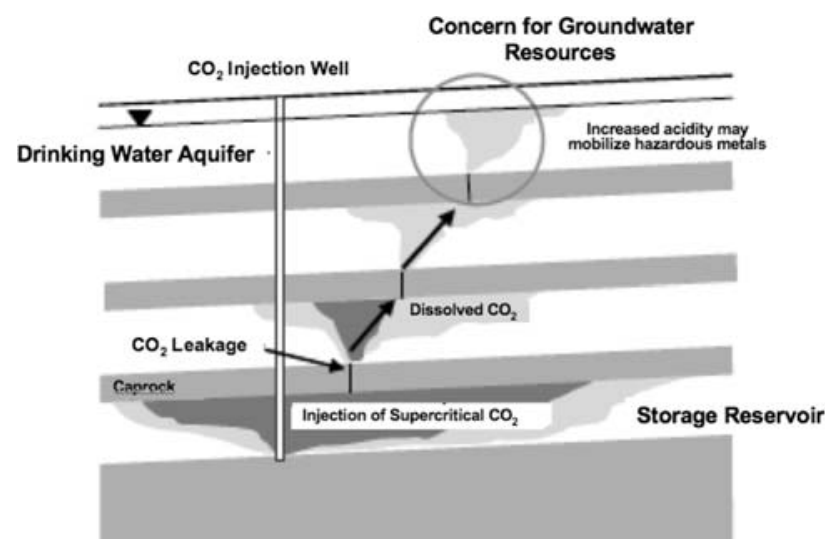

Fig. 7 Groundwater quality can change in response to $\mathrm{CO}_{2}$ leakage from deep geologic storage (after Xu and others 2007) the work of groups such as Gasda and others (e.g., Gasda and others 2004), and abundant industry experience in designing $\mathrm{CO}_{2}$ wells and plugging those that fail (e.g., Perry 2003). There is similar good experience in identifying and recompleting wells. However, there is still a challenge posed by the sheer number of active and inactive wells present in potential $\mathrm{CO}_{2}$ storage targets. There are $\sim 144,000$ Class II (oil and gas related injection) wells in operation in the US today (US EPA 2008a).

Risk is often defined as the product of the probability of an event and its consequence. Several recent efforts have discussed the risks associated with geologic storage (e.g., Price and others 2007; Wilson and others 2007; CEC 2007). There is abundant analog information about the leakage risks from related industries, including oil and gas exploration and production, natural gas storage, acid gas disposal, hazardous waste programs and natural and engineered analogs. There is general agreement that the operational risks for CCS would be no greater and likely less than the oil and gas equivalents because $\mathrm{CO}_{2}$ is not flammable or explosive (Benson and Heppel 2005a). It is generally not dangerous except in fairly high concentrations $(>15,000$ $\mathrm{ppm})$. Physiological tolerance time for $\mathrm{CO}_{2}$ concentrations below $1 \%$ by volume $(10,000 \mathrm{ppm})$ are listed as indefinite (EPA 2008b), although the NIOSH recommended 8-h exposure limit is 5,000 ppm (NIOSH 2008). There is long industrial experience with the tools and methodologies for handling gases in the field and preventing and mitigating leakage when it occurs. Moreover, leakage risks are expected to be small for a well-chosen and operated site. The actual fluxes are likely to be small; the health, safety and environmental consequences would be similarly small.

There is excellent experience in leakage and mitigation from the natural gas storage and oil industries. Lewicki and others (2007a) compiled a comprehensive study of leakage from both naturally occurring and industrial $\mathrm{CO}_{2}$ reservoirs. Most leaks occurred via either unsealed fault and fracture zones or through improperly constructed or abandoned wells. The leakage itself was quite variable, and while changes to groundwater chemistry were related to the $\mathrm{CO}_{2}$ leakage, waters often remained potable. In a study of leaks occurring in natural gas storage fields (Perry 2003; Kuuskraa 2007), half the cases were through wellbore and casing, and were corrected with wellbore remediation and well plugging. Of the remaining leaks that occurred through cap rock and seal, two were corrected with pressure control or gas capture and recycling. The remaining three fields were abandoned. Since most of these cases occurred pre-1970, it was suggested that modern construction and operations would likely prevent such leaks from occurring. In addition to leakage, $\mathrm{CO}_{2}$ well blowouts have occurred; in a recent study (Skinner 2003), four out of five cases occurred during remedial work. Recommendations were made for improved 
work procedures, training and diagnostics to prevent such events.

There is similar experience in mitigation and remediation when leakage does occur from the gas storage and oil industry. Recommendations are being developed utilizing such industry experience (e.g., Benson and Hepple 2005b; Kuuskraa 2007). Common elements occur, including pressure controls (e.g., lowering injection pressure, lowering formation pressure, increasing pressure in the leakage zone), remediating the leak and recovering migrating $\mathrm{CO}_{2}$.

While there are numerous examples of $\mathrm{CO}_{2}$ leakage at various rates to the atmosphere from natural and industrial sources (e.g., Lewicki and others 2007a, b), there is less information on leakage to shallow aquifers. Concerns have been raised regarding the potential for $\mathrm{CO}_{2}$-bearing brine leakage leading to mobilization of toxic species from overlying drinking water supplies (e.g., Kharaka and others 2006). Recent studies have focused specifically on leakage from a storage reservoir into overlying formations. Carroll and others (2009) conducted a study of the chemical response of a $\mathrm{CO}_{2}$ leak into a carbonate aquifer with characteristics of the High Plains Aquifer in the U.S. mid-continent. Equilibrium calculations demonstrated the rapid decrease of $\mathrm{pH}$ along with increases in alkalinity as $\mathrm{HCO}_{3}{ }^{-}$, p $\mathrm{CO}_{2}$ and total dissolved carbon. Sensitivity studies using reactive transport modeling explored the behavior of the dissolved $\mathrm{CO}_{2}$ arising from different initial flux rates as it rose to the top of the formation and spread out. A downstream irrigation well continued to pump throughout the simulation, and the capture of $\mathrm{CO}_{2}$-rich fluids was modeled. In all cases, detection of leakage was possible at distance because pumping effectively transported the $\mathrm{CO}_{2}$-rich fluids to the monitoring well. Changes in $\mathrm{pH}$ were readily measured and remained within the range for natural waters, even for a high flux case $\left(10^{5}\right.$ ton/year).

\section{Interactions with groundwater}

The primary concern of leakage of $\mathrm{CO}_{2}$-rich fluids leaking into a groundwater resource is the potential mobilization of hazardous inorganic constituents due to the increased acidity these fluids generate. Birkholzer and others (2008) systematically evaluated the potential hydrochemical impacts of $\mathrm{CO}_{2}$ storage projects on U.S. drinking waters, utilizing water quality analyses from the USGS NWIS database. Thermodynamic equilibrium modeling revealed the aqueous concentration of various species in equilibrium with commonly-occurring minerals. The most problematic species include lead and arsenic, which could exceed maximum concentration limits (MCLs) under some conditions, depending such factors as $\mathrm{CO}_{2}$ injection rate, adsorption potential and the degree of buffering available in the host reservoir.
Groundwater protection is the focus of the U.S. Environmental Protection Agency's (EPA) Underground Injection Control (UIC) Program. The EPA has released a proposed rule stating the federal requirements under the UIC Program for $\mathrm{CO}_{2}$ geologic sequestration wells under the Safe Drinking Water Act (EPA 2008c). Multiple organizations are developing guidelines and recommendations to inform the emerging regulatory frameworks, including efforts by the Interstate Oil and Gas Compact Commission (IOGCC 2007) and non-governmental organizations (e.g., World Resources Institute 2008). Innovations are being made at the individual state level in terms of policy, legal and regulatory frameworks (e.g., Anderson 2008; California 2007; Kansas 2007; New Mexico 2007; Washington 2007; Wyoming 2008). Important features to be addressed include geologic characterization, fluid movement, area of review, well construction, operations, mechanical integrity testing, measurement, monitoring and verification (MMV), site closure, post-closure monitoring, risk assessment/management, financial responsibility and public acceptance. The DOE's Regional Carbon Sequestration Partnerships are addressing these issues on a regional basis as they assess the sequestration resource in the region, conduct small Phase II scale field tests as part of the validation phase and prepare to conduct large volume Phase III $\mathrm{CO}_{2}$ storage tests.

It is the large scale required for commercial deployment that is the primary challenge for CCS. Consider a thought experiment: by 2020, all new coal plants will be fitted for $\mathrm{CO}_{2}$ capture and storage. Each $1000 \mathrm{MW}$ plant will generate from 5-8 million tons of $\mathrm{CO}_{2}$ per year, between 120,000 and $200,000 \mathrm{bbl} / \mathrm{d}$ of $\mathrm{CO}_{2}$ as supercritical phase. After 10 years of injection, the $\mathrm{CO}_{2}$ plume radius for that plant will extend to $\sim 10 \mathrm{~km}$ (depending on sequestration reservoir configuration); by 50 years, it will be $\sim 30 \mathrm{~km}$ radius. There will likely be many hundreds of wells involved in the sequestration processes, with injection into multiple stacked reservoirs.

\section{Energy-Water Nexus Opportunity}

There is a potential opportunity to take advantage of the linkage between electric power production, water supplies and CCS. Several outstanding issues can be addressed through integrated action, with beneficial results. It is generally acknowledged that electric power generation uses large volumes of water (e.g., Hutson and others 2004; DOE 2007; DOE-NETL 2007a). Commercial-scale deployment of CCS will involve significant displacement of reservoir fluids; in saline formations, these fluids will be brines. Long-term injection increases formation pressures, which is an operational issue especially with multiple CCS projects operating in a regional reservoir. Finally, a key issue in desalination is brine condensate disposal. 
In a commercial-scale operation, an option to consider is extracting some of the brine and treating it for beneficial use (Fig. 8). This approach simultaneously addresses all three issues and creates an opportunity for inland desalination, whereby fresh water supplies are increased where they are needed (potentially to offset some of the power plant water needs), and the brine condensate can be disposed by reinjection, potentially as part of the sequestration operations. The energy penalty of treatment would need to be addressed in the overall economic analysis. However, the aquiferpressured fluids provide all or part of the inlet pressure for the desalination system, reducing the overall treatment cost (Aines and others 2009; Wolery and others 2009). The volumes over the lifetime of a project are immense, some 24 billion barrels (e.g., MIT 2007). A coarse estimate has been made that, for a modern $1 \mathrm{GW}$ IGCC plant generating 7.5 million $\mathrm{m}^{3}$ of $\mathrm{CO}_{2} /$ year, treating displaced brine would provide half of the plant's operating fresh water, including cooling requirements (Aines and others 2009, Wolery and others 2009). Given the trend toward utilizing non-traditional water supplies for power plant process and cooling water, and the increased reuse of power plant water, on-site water treatment is on the increase already. This would constitute a scaled-up application of industrial ecology, locally offsetting generation water needs (moving toward a zero-impact power plant), and combining CCS with desalination and increasing water supply for beneficial use.

While attractive, there are some challenges involved in this approach. An important one is the varying composition of CCS target formation waters. While there are a number of technologies commercially available to treat water of low quality, only a handful are applicable to desalination of highly saline waters or seawater. These include reverse osmosis (RO), distillation, electodialysis and vacuum freezing. RO is the most widely-applied method for seawater desalination or highly saline waters. It is almost

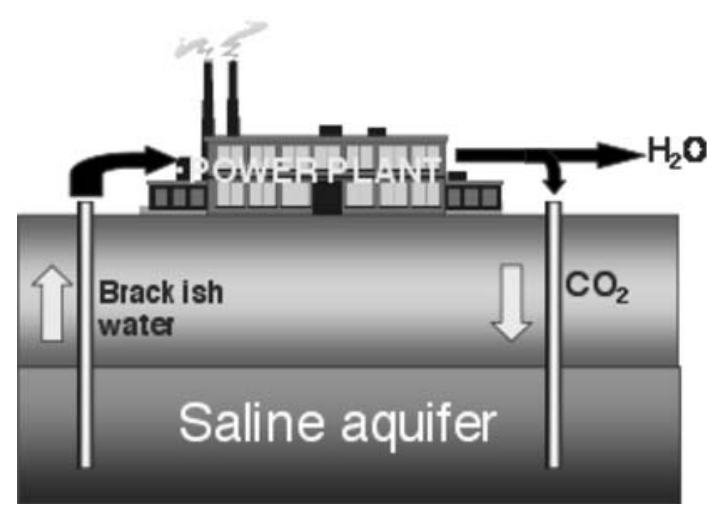

Fig. 8 Treating displaced brine could both increase storage capacity through pressure reduction in the reservoir and provide fresh water for beneficial use; brine condensate could be injected into the storage reservoir (after Aines and others 2009) always coupled with a pretreatment step to minimize fouling by silt, organic or inorganic debris. Thus, some kind of filtration is commonly applied. Pretreatment also addresses scaling issues; in truth, most treatment methodologies require some level of pre-treatment to adjust the feed stream for optimal operation. The complexity in considering coupling CCS with desalination is the wide range of chemical compositions that could potentially be involved. A set of formation chemistries from candidate CCS reservoirs in Wyoming includes sodium- and chloride-dominated waters very similar to seawater as well as sulfate-dominated waters (Fig. 9). Moreover, compositions can vary within similar lithologies (both sulfate and chloride-dominated compositions in sandstones) as well as within a single unit (two very different chemical compositions in the Madison Formation). Treatment would require careful design to optimize a system for the specific input composition.

\section{Research Opportunities}

Commercial-scale deployment of CCS will require a greater level of understanding of the complex behavior of natural systems to the large volumes of $\mathrm{CO}_{2}$ injected over long timeframes than is currently available. This understanding can be obtained by coordinated studies integrating laboratory studies, simulations and site-specific field tests. Modeling and simulations will be needed as critical underpinnings for performance-based standards. Such standards have been suggested by the recent release of the U.S. Environmental Protection Agency's proposed federal requirements for geologic sequestration of carbon dioxide (EPA 2008c). While current simulations are relatively simplistic, actual injection projects will need to address a greater level of complexity, including the following heterogeneities inherent in natural systems; realistic leakage complexities posed by multiple injectors, likely of varying construction; coupled geomechanics; and multiple injection projects in regional hydrology.

Some work is already in progress. For example, Pawar and Stauffer (2007) have developed numerical capabilities that can be used to simulate detailed wellbore/near wellbore behavior in a large-scale sequestration operation, Birhkolzer, Zhou and others (e.g., Zhou and others 2008) are investigating the impact of large-scale $\mathrm{CO}_{2}$ injection and storage on regional multilayered groundwater systems. The DOE Regional Partnership Phase III projects offer an excellent opportunity to conduct coordinated assessments of the far-field pressure response both within the injection zone and in the overlying aquifers. Even the smaller, Phase II projects provide unique opportunities to conduct integrated studies (laboratory, simulations, site-specific field test) to calibrate modes, especially those pertaining to geochemical responses. 
Fig. 9 Water chemistries from potential CCS target formation can vary widely, even within a lithology or a formation. (Data courtesy of Vicki Camp, RMOTC, and Geoffrey Thyne, University of Wyoming 2008)

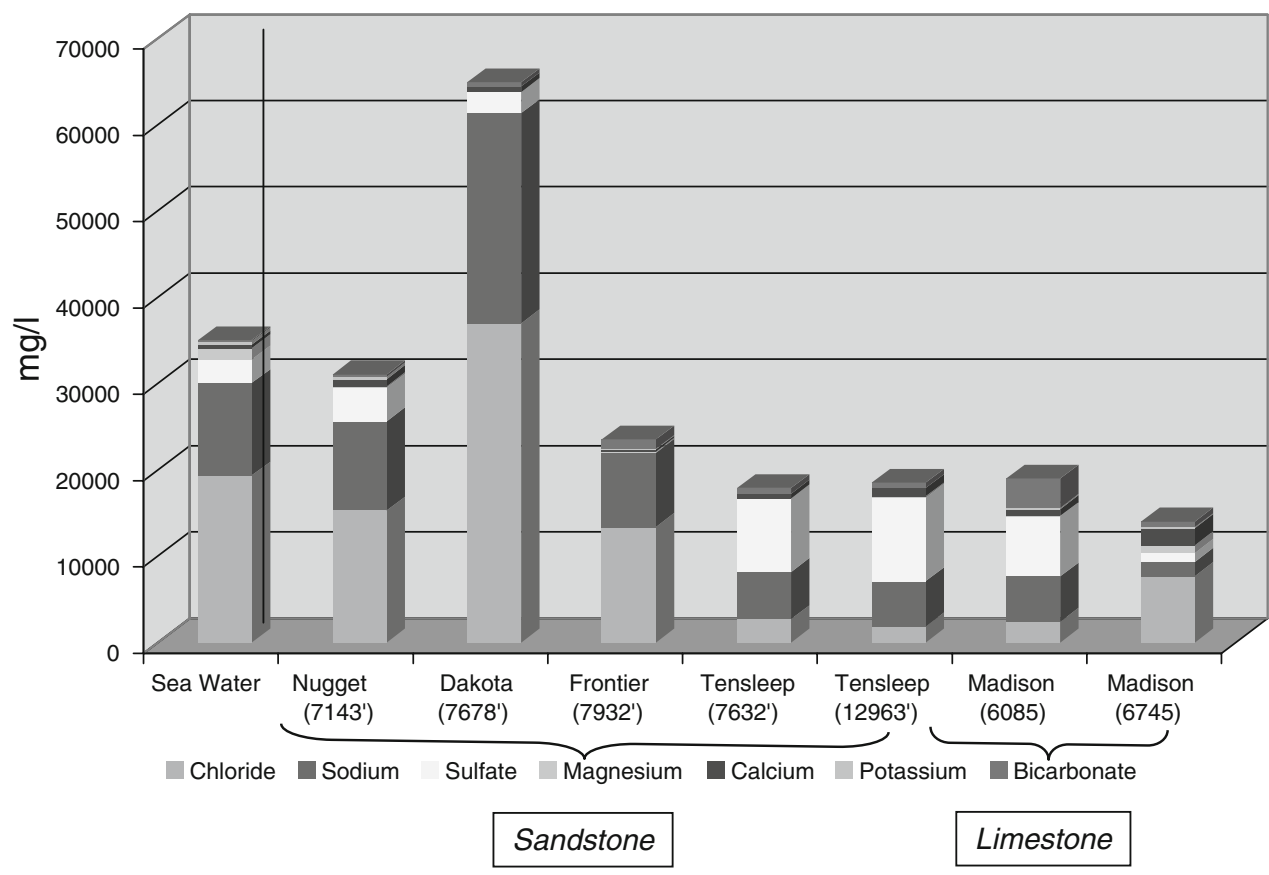

In addition, there is opportunity to improve reservoir management as operations become more routine. As in similar industries (e.g., oil and gas extraction, enhanced oil recovery), as projects are conducted and users become more familiar with the processes, proactive reservoir management options can be explored. Such improvements often result in better economics for full-scale operations.

\section{Summary}

Large-scale CCS deployment presents some challenges to water resources. Potential impacts range from increasing water demand for carbon capture, to potential contamination of groundwater through leakage or brine displacement. These impacts and the conditions under which they arise are reasonably well understood. The scientific and technology gaps between current practice and operations at commercial scale appear to be resolvable and ongoing efforts are underway to address system performance under expanded temporal and spatial conditions. While there are inherent risks associated with $\mathrm{CO}_{2}$ injection and storage, they can be managed. A critical consideration is the initial choice of a good site, based on criteria for capacity, injectivity and effectiveness.

Appropriate monitoring will be important, both for assurance of environmental safety and for accounting purposes. Leakage is a credible concern, and deployment must be designed and operated to avoid it. However, if leakage does occur, it can be detected and there are known mitigation methods for remediation, although implementation will likely be costly and may affect operations.

Depending on the technologies deployed, water usage can increase with CCS. Some increases in water use may be offset by extracting water from the storage reservoir and treating it for beneficial use. This has the added benefit of reducing reservoir pressure, effectively increasing sequestration capacity.

The biggest uncertainties in CCS implementation derive from the scale of deployment. It is critical that demonstrations be conducted at sufficient scale and with sufficient monitoring to evaluate performance and confirm projections; in short, to confirm expectations and to learn what we do not know.

Acknowledgments This work was performed under the auspices of the U.S. Department of Energy by Lawrence Livermore National Laboratory under Contract DE-AC52-07NA27344. This document was prepared as an account of work sponsored by an agency of the United States government. Neither the United States government nor Lawrence Livermore National Security, LLC, nor any of their employees makes any warranty, expressed or implied, or assumes any legal liability or responsibility for the accuracy, completeness, or usefulness of any information, apparatus, product, or process disclosed, or represents that its use would not infringe privately owned rights. Reference herein to any specific commercial product, process, or service by trade name, trademark, manufacturer, or otherwise does not necessarily constitute or imply its endorsement, recommendation, or favoring by the United States government or Lawrence Livermore National Security, LLC. The views and opinions of authors expressed herein do not necessarily state or reflect those of the United States government or Lawrence Livermore National Security, LLC, and shall not be used for advertising or product endorsement purposes. 
We acknowledge three anonymous reviewers for their meaningful suggestions.

Open Access This article is distributed under the terms of the Creative Commons Attribution Noncommercial License which permits any noncommercial use, distribution, and reproduction in any medium, provided the original author(s) and source are credited.

\section{References}

Aines RD, Wolery TJ, Hao Y, Bourcier WL (2009) Fresh water generation from aquifer-pressured carbon storage: interim progress report, LLNL-TR-415027, July 2009

Anderson S (2008) Innovation at the state level in policy, legal and regulatory frameworks for geological $\mathrm{CO} 2$ sequestration, 7th Annual Conference on Carbon Capture and Sequestration, May, 2008

Benson SM, Hepple RP (2005a) Prospects for early detection and options for remediation of leakage from $\mathrm{COB} 2 \mathrm{~B}$ sequestration projects. In: Carbon dioxide capture for storage in deep geologic formations-results from the COB2B capture Project, vol 2: Geologic storage of carbon dioxide with monitoring and verification, Elsevier, UK, pp 1189-1203

Benson SM, Hepple RP (2005b) Detection and options for remediation of leakage from underground $\mathrm{CO}_{2}$ storage projects. In: Rubin ES, Keith DW, Gilboy CF (eds) Proceedings of the 7th international conference on greenhouse gas technologies. Elsevier, London

Birkholzer JA, Apps L, Zhent L, Zhang Y, Xu T (2008) Prediction of groundwater quality changes in response to $\mathrm{CO} 2$ leakage from deep geological storage, 2008. In: 7th annual conference on carbon capture and sequestration, May, 2008

California (2007) Policy report: geologic carbon sequestration strategies for California: the Assembly Bill 1925 report to the California State Legislature-Joint Agency Report. http://www. energy.ca.gov/publications/displayOneReport.php?pubNum= CEC-500-2007-100-CMF

California Energy Commission (CEC) (2007) Geologic carbon sequestration strategies for California: Report to the Legislature, Final Staff Report, CEC-500-2007-100-SF, November, 2007

Carroll SA, Hao Y, Aines RA (2009) Chemical detection of carbon dioxide in dilute aquifers. Geochemical Transactions 10:4

Crandell, LE, Ellis BR, Cheung J and Peters CA (2008) Injection of carbon dioxide and co-contaminant gases: are separation costs justifiable? In: Presented at the seventh annual conference on carbon capture \& sequestration, Pittsburgh, PA, May 5-8, 2008

DOE (2007) U.S. Department of Energy, energy demands on water resources, report to congress on the interdependency of energy and water, September 2006

DOE-NETL (2007a) U.S. Department of Energy, National Energy Technology Laboratory, power plant water usage and loss study, May 2007 revision

DOE-NETL (2007b) U.S. Department of Energy, National Energy Technology Laboratory, cost and performance baseline for fossil energy plants, vol 1. Bituminous coal and natural gas to electricity, Revision 1, August, 2007

DOE-NETL (2007c) U.S. Department of Energy, National Energy Technology Laboratory, estimating freshwater needs for thermoelectric generation, 2007

DOE-NETL (2008) U.S. Department of Energy, National Energy Technology Laboratory, carbon sequestration Atlas of the United States and Canada
EPA (2008a) U.S. Environmental Protection Agency, underground injection control program oil and gas related injection wells (Class II). http://www.epa.gov/safewater/uic/wells_class2.html

EPA (2008b) U.S. Environmental Protection Agency, appendix B: overview of acute health effects associated with carbon dioxide. http://209.85.141.104/search?q=cache:UleLqVUZZOkJ:www. epa.gov/ozone/snap/fire/co2/appendixb.pdf + co2 + health + effects + osha\&hl=en \&ct=clnk\&cd=7\&gl=us\&client=firefox-a

EPA (2008c) U.S. Environmental Protection Agency, federal requirements under the Underground Injection Control (UIC) Program for carbon dioxide (CO2) geologic sequestration (GS) wells; proposed rule, 40 CFR Parts 144 and 146, Federal Register vol. 73, No. 144, July, 2008, http://www.epa.gov/EPA-WATER/ 2008/July/Day-25/w16626.htm

EPRI (2004) Electric Power Research Institute, Comparison of alternate cooling technologies for U.S. power plants; economic, environmental and other tradeoffs (K. Zammit, Project Manager) Technical Report 1005358, August, 2004

Ferguson R, Van Leeuwen T, Kuuskraa V (2008) Storing CO2 with enhanced oil recovery. In: Presented at the 7th annual conference on carbon capture \& sequestration, Pittsburgh, PA, May 5-8, 2008

Friedmann SJ (2007) Operational protocols for geologic carbon storage: facility life-cycle and the new hazard characterization approach, sixth annual conference on carbon capture and sequestration, Pittsburgh, PA, May, 2007

Gasda SE, Bachu S, Celia MA (2004) The potential for CO2 leakage from storage sites in geological media: analysis of well distribution in mature sedimentary basins. Environmental Geology 46(6-7):707-720

Hutson SS, Barber NL, Kenny JF, Linsey KS, Lumia DS, Maupin MA (2004) Estimated use of water in the United States in 2000", Circular 1268. U.S. Geological Survey, Reston, VA, 2004. http:// water.usgs.gov/pubs/circ/

Interstate Oil and Gas Compact Commission (2007) Road to a greener energy future: $\mathrm{CO} 2$ storage: a legal and regulatory guide for states, December, 2007. http://iogcc.myshopify.com/collections/ frontpage/products/co2-storage-a-legal-and-regulatory-guide-forstates-2008

IPCC (2005a) UN Intergovernmental Panel on Climate Change, special report on carbon capture and storage: summary for policymakers, Geneva. http://www.ipcc.ch/pdf/special-reports/ srccs/srccs_wholereport.pdf

IPCC (2005b) Intergovernmental Panel on Climate Change, special report on carbon dioxide capture and storage 2005. In: Metz B, Davidson O, de Coninck H, Loos M, Meyer L (eds) Cambridge University Press. http://www.ipcc.ch/ipccreports/special-reports. htm

Johnson JW, Nitao JJ, Knauss KG (2004) Reactive transport modeling of $\mathrm{CO} 2$ storage in saline aquifers to elucidate fundamental processes, trapping mechanisms and sequestration partitioning. In: Baines SJ, Worden RH (eds) Geological storage of carbon dioxide, Geological Society, London, Special Publications, 233:107-128

Johnson JW, Nitao JJ, Morris JP (2005) Reactive transport modeling of cap-rock integrity during natural and engineered $\mathrm{CO} 2$ storage. In: Thomas DC, Benson SM (eds) Carbon dioxide capture for storage in deep geologic formations, vol 2. Elsevier, London

Kansas (2007) Regulations found at http://kansasstatutes.lesterama. org/Chapter_55/Article_16/, see 55-1636-1540

Kharaka YK, Cole, Hovorka SD, Gunter WD, Knauss KG, Freifeld BM (2006) Gas-water-rock interactions in Frio Formation following DO2 injection: implications for the storage of greenhouse gases in sedimentary basins. Geology 34(7):577-580

Kumar H, Gryant SL, Nicot JP, Oldenburg CJ (2007) Simplified models for plume dynamics; simulation studies for geological 
$\mathrm{CO} 2$ storage certification framework. In: Sixth annual conference on carbon capture and sequestration, May 2007

Kuuskraa VA (2007) Overview of mitigation and remediation options for geological storage of CO2, Staff Workshop on Technical Papers for AB1925 Report to the California Legislature, June, 2007. www.westcarb.org/pdfs_ab1925/Kuuskraa\%20_mitigation. pdf

Kuuskraa VA, Koperna GJ (2006) Evaluating the potential for 'game changer' improvements in oil recovery efficiency from $\mathrm{CO} 2$ enhanced oil recovery. In: Prepared for U.S. Department of Energy, Office of Fossil Energy-Office of Oil and Natural Gas, February, 2006

Lewicki JL, Birkholzer J, Tsang D-F (2007a) Natural and industrial analogues for leakage of $\mathrm{CO} 2$ from storage reservoirs: identification of features, events and processes and lessons learned, Environ. Geology 52:457-467, 2007. http://dx.doi.org/10.1007/ s00254-006-0479-7

Lewicki JL, Oldenburg CM, Dobeck L, Spangler L (2007b) Surface $\mathrm{CO} 2$ leakage during two shallow subsurface $\mathrm{CO} 2$ releases. Geophysical Research Letters 34:L24402. doi:10.1029/2007/ GL032047

Massachusetts Institute of Technology, MIT (2007) The future of coal: options for a carbon-constrained world, Cambridge, MA. http://web.mit.edu/coal/

NIOSH (2008) National Institute for Occupational Safety and Health Pocket guide to chemical hazards. http://www.cdc.gov/NIOSH/ npg/npgd0103.html

New Mexico (2007) Policy Report: carbon dioxide sequestration: interim report on identified statutory and regulatory issues. http://www.emnrd.state.nm.us/ocd/documents/InterimReportCO2 Sequestration.pdf

Nicot JP (2008) Evaluation of large-scale CO2 storage on fresh-water sections of aquifers: an example from the Texas Gulf Basin. International Journal of Greenhouse Gas Control. doi:10.1016/ j.ijggc.2008.03.004

Pawar RJ, Stauffer PH (2007) Numerical simulations of large-scale $\mathrm{CO} 2$ injection incorporating effect of potential wellbore leakage. In: Sixth annual conference on carbon capture and sequestration, May, 2007

Perry K (2003) Natural gas storage experience and CO2 storage, report prepared for the $\mathrm{CO} 2$ Capture Project by the Gas Technology Institute, July, 2003
Price PN, McKone T, Sohn MD (2007) PIER white paper on Carbon Sequestration Risks and Risk Management, CEC, 2007

Skinner L (2003) $\mathrm{CO}_{2}$ blowouts: an emerging problem. WorldOil Magazine 224(1). http://www.worldoil.com/magazine/ MAGAZINE_DETAIL.asp?ART_ID=1921\&MONTH_YEAR= Jan-2003

Washington (2007) Rulemaking: Chapter 173-407 WAC-Carbon dioxide mitigation program for fossil-fueled thermal electric generating facilities and Chapter 173-218 WAC-Underground injection control program. http://www.ecy.wa.gov/laws-rules/ activity/wac173407_218.html

Wilson EJ, Friedmann SJ, Pollak MF (2007) Research for deployment: capture and sequestration, incorporating risk, regulation and liability for carbon capture and sequestration. Environmental Science and Technology 41:5945-5952

Wolery TJ, Aines RD, Hao Y, Bourcier W, Wolfe T, Haussman C (2009) Fresh water generation from aquifer-pressured carbon storage: Annual Report FY09, LLNL-TR-420857, 46 p

World Energy Council (2004) 2004 Survey of Energy Resources. http://www.worldenergy.org.publications/324/asp

World Energy Council (2007) 2007 Survey of Energy Resources. http://www.worldenergy.org/publications/survey_of_energy_ resources_2007/default.asp

World Resources Institute (2008) Carbon Capture and Sequestration (CCS). http://www.wri.org/project/carbon-capture-sequestration

Wyoming (2008) Legislation -HB 89: Ownership of subsurface pore space. http://legisweb.state.wy.us/2008/Summaries/HB0089.htm and HB 90:Carbon capture and sequestration, http://legisweb. state.wy.us/2008/Summaries/HB0090.htm

Xu T, Apps JA, Birkholzer JT (2007) Contamination of groundwater by hazardous inorganic chemical constituents through induced acidification due to $\mathrm{CO}_{2}$ leakage from a storage formation. In: Abstract in proceedings 6th annual conference on carbon capture and sequestration, Pittsburgh, PA, May 2007

Zhou QJ, Birkholzer J, Tsang C-F (2008) Environmental impact of large-scale $\mathrm{CO} 2$ injection and storage in a multi-sequence aquifer-seal system: pressure propagation and brine displacement. In: 7th annual conference on carbon capture \& sequestration, Pittsburgh, Pennsylvania, May 2008 